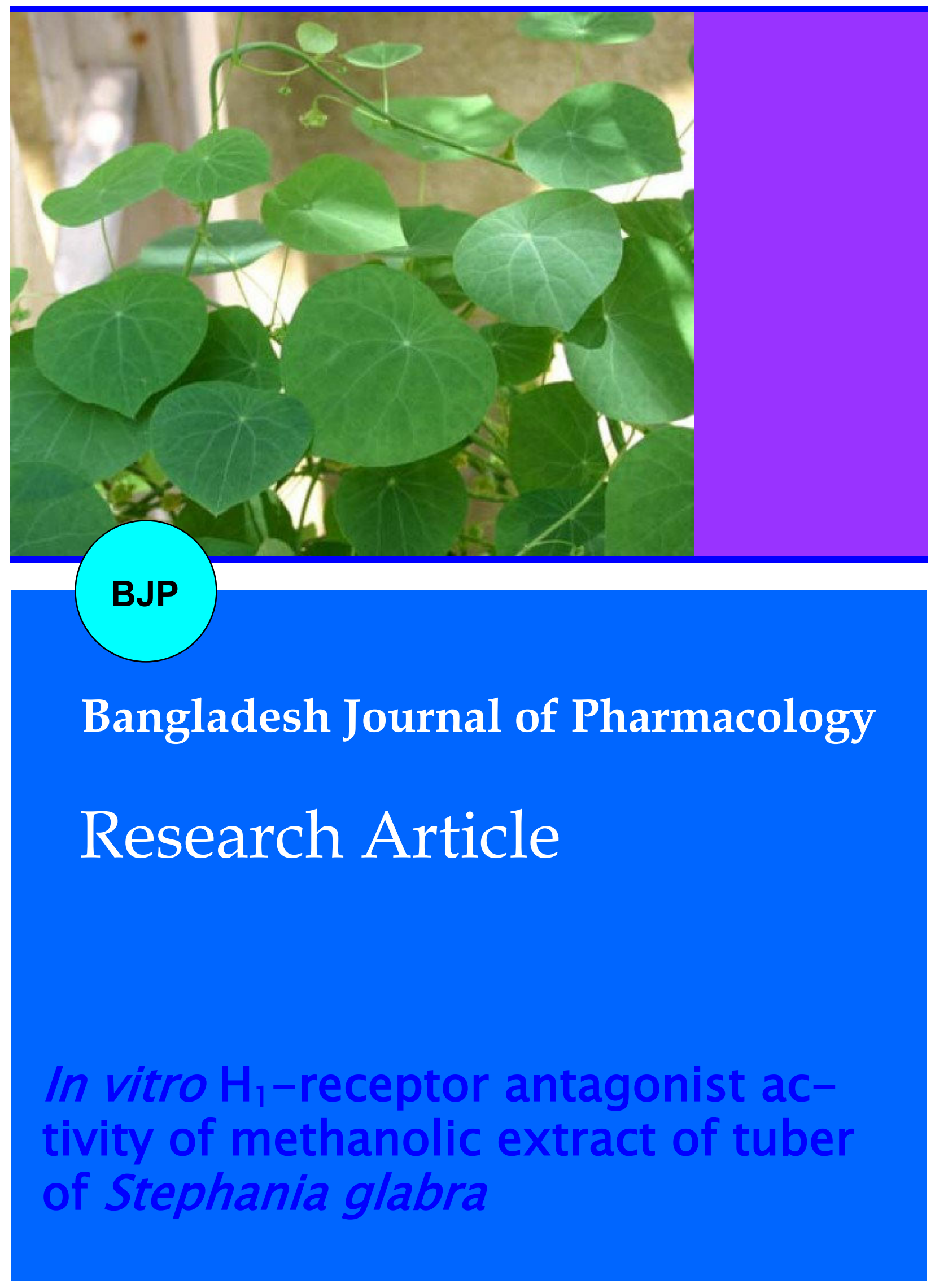




\title{
In vitro $\mathrm{H}_{1}$-receptor antagonist activity of methanolic extract of tuber of Stephania glabra
}

\author{
Nisar Ahmad Khan', Dinesh Kumar', Zulfiqar Ali Bhat', Vijender Kumar', Navneet \\ Nagpal $^{2}$ and Santosh S. Bhujbal3
}

${ }^{1}$ Department of Pharmaceutical sciences, University of Kashmir, Srinagar 190 006, Jammu \& Kashmir; ${ }^{2}$ B.I.S. College of Pharmacy, Gagra, Moga 142 103, Punjab; ${ }^{3}$ Padam Shree Dr. D. Y. Patil IPSR, Pimpri 18, Pune, India.

\begin{tabular}{|c|c|}
\hline \multicolumn{2}{|l|}{ Article Info } \\
\hline Received: & 25 November 2009 \\
\hline Accepted: & 24 February 2010 \\
\hline Available Online: & 3 March 2010 \\
\hline \multicolumn{2}{|c|}{ DOI: $10.3329 /$ bjp.v5i2.6671 } \\
\hline \multicolumn{2}{|c|}{$\begin{array}{l}\text { Cite this article: } \\
\text { Khan NA, Kumar D, Bhat ZA, Kumar } \\
\text { V, Nagpal N, Bhujbal SS. In vitro } \mathrm{H}_{1}- \\
\text { receptor antagonist activity of meth- } \\
\text { anolic extract of tuber of Stephania } \\
\text { glabra. Bangladesh J Pharmacol. 2010; } \\
\text { 5: 89-91. }\end{array}$} \\
\hline
\end{tabular}

\section{Abstract}

In the present study, methanolic extract of tuber of Stephania glabra was evaluated for $\mathrm{H}_{1}$-bloker activity by employing in vitro screening models of guinea pig ileum and goat tracheal chain preparation. Goat isolated trachea and guinea pig ileum contracted to histamine in a dose-dependent manner while chlorpheniramine blocked this effect. The methanolic extract produced significant dose-dependent $\mathrm{H}_{1}$-receptor antagonist activity by blocking histamine-induced contraction.

\section{Introduction}

Herbal medicines are being increasingly utilized to treat a wide variety of diseases, though the knowledge about their mode of action is relatively scanty. So there is a growing interest regarding the pharmacological evaluation of various plants used in traditional system of medicine (Biswas et al., 2009). The genus Stephania belongs to family Menispermaceae, a large family of about 65 genera and 350 species, distributed in warmer parts of the world. Over 150 alkaloids together with flavonoids, lignans, steroids, terpenoids and coumarins have been identified in the genus, and many of these have been evaluated for biological activity. Stephania glabra Vern. is a large, climbing shrub, indigenous to lower Himalaya of India. The tubers of the plant used for the treatment of variety of disorders, including asthma, tuberculosis, dysentery and fever. It is used as psycomedicine by natives in India (James, 1992; CSIR, 1989). More than thirty alkaloids of different classes have been isolated from the plant (Semwal and Rawat, 2009). The present study is designed to investigate the $\mathrm{H}_{1}$-blocker activity.

\section{Materials and Methods}

\section{Plant material}

The plant was collected from Dhamrol of Hamirpur district, Hondra Prodesh, India and was authenticated from the Regional Research Institute as voucher specimen No. 649 by Dr. Rajesh Dabur.

\section{Preparation of extracts}

The tuber was dried under shade, coarsely powdered and passed through 40 mesh sieves. The powdered material $(500 \mathrm{~g})$ was extracted with methanol using Soxhlet apparatus. The extract obtained was dried in rotary vacuum evaporator at $40^{\circ} \mathrm{C}$, yielding a dark brown color viscous mass $25 \mathrm{~g}(5.0 \%)$.

\section{Animals}

Guinea pigs (300-400 g) of either sex were procured from National toxicological centre, Pune, India. The animals were housed for 2 weeks prior to the experiment for acclimatization in the animal house of 


\begin{tabular}{|c|c|c|c|}
\hline \multicolumn{4}{|c|}{ Table I } \\
\hline \multicolumn{4}{|c|}{$\begin{array}{c}\text { Effect of methanol extract of the tuber of Stephania glabra on histamine-induced contraction in isolated } \\
\text { guin-ea pig ileum }\end{array}$} \\
\hline \multirow{2}{*}{$\begin{array}{l}\text { Histamine concentra- } \\
\text { tion }(\mu \mathrm{g} / \mathrm{mL})\end{array}$} & \multicolumn{3}{|c|}{$\%$ Contraction of isolated guinea pig ileum } \\
\hline & None & $\begin{array}{l}\text { Methanol extract } \\
(100 \mu \mathrm{g} / \mathrm{mL})\end{array}$ & $\begin{array}{c}\text { Chlorpheniramine } \\
(10 \mathrm{~g} / \mathrm{mL})\end{array}$ \\
\hline 1 & $45.1 \pm 1.2$ & $20.2 \pm 1.4^{b}$ & $18.3 \pm 1.0^{\mathrm{b}}$ \\
\hline 2 & $65.4 \pm 2.1$ & $30.4 \pm 1.7 \mathrm{~b}$ & $30.1 \pm 1.7 \mathrm{~b}$ \\
\hline 4 & $68.9 \pm 2.3$ & $42.8 \pm 2.8^{b}$ & $34.3 \pm 1.1^{b}$ \\
\hline 8 & $84.4 \pm 1.6$ & $48.4 \pm 2.4^{b}$ & $38.2 \pm 1.3^{b}$ \\
\hline 16 & $86.6 \pm 1.7$ & $59.2 \pm 2.0^{\mathrm{b}}$ & $46.1 \pm 0.9^{b}$ \\
\hline 32 & $100.0 \pm 1.7$ & $64.4 \pm 2.2^{b}$ & $51.4 \pm 0.9 b$ \\
\hline
\end{tabular}

Institute. Animals were maintained under controlled conditions of temperature $26 \pm 2^{\circ} \mathrm{C}$, relative humidity $44-56 \%$, and photo-schedule (12 hours light/dark). Animals were provided with standard diet (Amrut feeds, Mumbai, India) and water ad libitum. The food was withdrawn 18 hours, before the start of the experiment. Institutional Animal Ethics Committee approved the experimental protocol (198/99/ CPCSEA/17). The pharmacological work was carried out as per norms of CPCSEA (Committee for the Purpose of Control and Supervision of Experiments on Animals).

Effect of test drug on isolated guinea pig ileum preparation

Overnight fasted guinea pig was sacrificed and ileum was mounted in an organ bath containing Tyrode solution. The Tyrode solution was continuously aerated and maintained at $37 \pm 0.5^{\circ} \mathrm{C}$. The tissue was allowed to equilibrate for $30 \mathrm{~min}$. under a load of $500 \mathrm{mg}$, contact time of $30 \mathrm{sec}$. and the response of Histamine was recorded by $5 \mathrm{~min}$ time cycle. After obtaining a dose response curve of histamine $(10 \mu \mathrm{g} / \mathrm{mL})$ on ileum, Methanolic extract of tuber of $S$. glabra $(100 \mu \mathrm{g} / \mathrm{mL})$ was added to the reservoir and same doses of histamine were repeated in presence of extract. Same procedure was repeated for standard drug (chlorpheniramine 10 $\mu \mathrm{g} / \mathrm{mL}$ ) as methanolic extract. Graph of percentage of maximum contractile response on ordinate and negative logarithm of molar concentration of histamine on abscissa was plotted to record dose response curve of histamine, in absence and presence of extract and standard drug (Kumar et al., 2010a).

Effect of test drug on isolated goat trachea chain preparation

Isolated adult goat tracheal tissue was obtained immediately after slaughter of the animals (Kumar et al., 2010b). Trachea was cut into individual rings and tied together in series to form a chain. Trachea was suspended in bath of Kreb's solution of the composition: $\mathrm{NaCl} 6.9, \mathrm{KCl} 0.35, \mathrm{CaCl}_{2}$ 0.28, $\mathrm{MgSO}_{4}$ $0.28, \mathrm{NaHCO}_{3} 2.1, \mathrm{KH}_{2} \mathrm{PO}_{4} 0.16$ and glucose $2.0 \mathrm{~g} / \mathrm{L}$, which was continuously aerated and maintained at $37 \pm$ $0.5^{\circ} \mathrm{C}$. One end of the tracheal chain was attached to an S-shaped aerator tube and other attached to an isotonic frontal writing lever to smoked drum (magnification 10 -12-fold). Tissue was allowed to equilibrate for $45 \mathrm{~min}$. Under a load of $400 \mathrm{mg}$ (NagChaudhari and Lahiri, 1974). A dose response curve for histamine was taken by maintaining $15 \mathrm{~min}$ time cycle. After obtaining a dose response curve of histamine on trachea, the methanol extract/chlorpheniramine were added to the respective reservoir and same doses of histamine were administered repeatedly. Graph of percentage of maximum contractile response on ordinate and negative logarithm of molar concentration of histamine on abscissa were plotted to record dose response curve of histamine, in absence and in presence methanol extract/chlorpheniramine.

\section{Statistical analysis}

The statistical analysis was performed by using Student's t-test, one-way analysis of variance (ANOVA) Followed by Dunnett's test for individual comparison of groups with control.

\section{Results}

Histamine showed dose-dependent contraction of smooth muscles. The methanol extract $(100 \mu \mathrm{g} / \mathrm{mL})$ inhibited histamine-induced contraction of isolated guinea pig ileum (Table I) and goat tracheal chain preparation (Table II) significantly $\left({ }^{a} \mathrm{p}<0.05,{ }^{b} \mathrm{p}<0.01\right)$.

\section{Discussion}

Histamine is a chemical mediator in the body, excessive release of which produces the variable effects on the airway smooth muscle of mammalian species. It has 


\begin{tabular}{|c|c|c|c|}
\hline \multicolumn{4}{|c|}{ Table II } \\
\hline \multicolumn{4}{|c|}{$\begin{array}{c}\text { Effect of methanol extract of Stephania glabra on histamine-induced contraction in isolated goat tracheal } \\
\text { chain preparation }\end{array}$} \\
\hline \multirow{2}{*}{$\begin{array}{l}\text { Histamine concentra- } \\
\text { tion }(\mu \mathrm{g} / \mathrm{mL})\end{array}$} & \multicolumn{3}{|c|}{$\%$ Contraction of isolated goat tracheal chain preparation } \\
\hline & None & $\begin{array}{l}\text { Methanol extract } \\
(100 \mu \mathrm{g} / \mathrm{mL})\end{array}$ & $\begin{array}{l}\text { Chlorpheniramine } \\
(10 \mu \mathrm{g} / \mathrm{mL})\end{array}$ \\
\hline 1 & $20.9 \pm 1.2$ & $14.6 \pm 0.8$ & $15.3 \pm 0.7$ \\
\hline 2 & $35.4 \pm 1.3$ & $19.9 \pm 0.9 a$ & $22.3 \pm 0.8^{b}$ \\
\hline 4 & $45.0 \pm 1.3$ & $28.5 \pm 1.9 \mathrm{a}$ & $28.7 \pm 1.1^{b}$ \\
\hline 8 & $64.6 \pm 1.7$ & $35.1 \pm 1.0^{a}$ & $38.0 \pm 1.1^{b}$ \\
\hline 16 & $74.1 \pm 3.5$ & $39.4 \pm 1.6^{\mathrm{a}}$ & $40.3 \pm 2.1^{b}$ \\
\hline 32 & $89.1 \pm 2.5$ & $48.7 \pm 1.1^{b}$ & $45.5 \pm 2.1^{b}$ \\
\hline 64 & $100.0 \pm 3.4$ & $60.3 \pm 1.2^{c}$ & $54.5 \pm 2.4^{b}$ \\
\hline
\end{tabular}

role in various diseases like asthma, bronchitis, cough, infla-mmation and allergic disorders. Histamine contracts the tracheo-bronchial muscle of guinea pig, goat, horse, dog and man. Goat tracheal chain is easier to handle and to prepare; it is also much more sensitive than guinea pig tracheal chain. In the present study of effect of test drug on the isolated goat tracheal chain preparation; there is right side shift of dose response curve of histamine in the presence of methyl extract and chlorpheniramine indicating antihistamine action (Bhujbal et al., 2009). Guinea pig ileum is also used for screening of antihistaminic activity. The stimulation of $\mathrm{H}_{1}$-receptors produces graded dose-related contraction of isolated guinea pig ileum. The extract $(100 \mu \mathrm{g} / \mathrm{mL})$ significantly inhibited the histamine induced contraction of isolated guinea pig ileum and goat tracheal chain preparations, indicating its $\mathrm{H}_{1}$-receptor antagonistic activity. The antihistamine activity showed by the plant may be because of the chemical moieties (Saraf and Patwardhan, 1998; Bouic and Lamprecht, 1999). However this claim demands for further research and the studies are infect underway to isolate and characterize the active principles responsible for the activity.

\section{Acknowledgement}

The authors are very much thankful to the authorities of Regional Research Institute, India for extending the cooperation during the authentication of the plant.

\section{References}

Bhujbal SS, Kumar D, Deoda RS, Deore TK, Patil MJ. Anti- asthmatic activity of roots of Hemidesmus indicus R. Br Pharmacol Online. 2009; 1: 209-16.

Biswas K, Kumar A, Babaria BA, Prabhu K, Setty SR. Hepatoprotective effect of leaves of Peltophorum pterocarpum against paracetamol induced acute liver damage in rats. J Basic Clin Pharm. 2009; 1: 10-15.

Bouic PJ, Lamprecht JH. Plant sterols and sterolins: A review of their immune-modulating properties. Altern Med Rev. 1999; 4: 170-77.

CSIR, The wealth of India, Vol. X $(\mathrm{Sp}-\mathrm{W})$. Row materials publication and information directorate CSIR, New Delhi, $1989, \mathrm{p} 41$.

James A. Handbook of phytochemical constituents of GRAS herbs and other economic plants. CRC Press, Boca Raton, Florida, 1992.

Kumar D, Bhujbal SS, Deoda RS, Mudgade SC. In vitro and in vivo antiasthmatic studies of Ailanthus excelsa Roxb. on guinea pigs. J Sci Res. 2010a; 2: 196-202.

Kumar D, Bhujbal SS, Patil PS, Buge PV. In vitro and in vivo activities of stem bark of methanolic extract of Ailanthus excelsa Roxb. in the management of asthma. Int J Pharmacol. 2010b; 6: 284-89.

NagChaudhari AK, Lahiri SC. Use of Goat trachea isolated tracheal chain preparation. Indian J Pharmacol. 1974; 6: 14951.

Saraf M, Patwardhan BK. Pharmacological studies on Sarcostemma brevistigma Whight part II: Bronchodilator activity. Indian Drugs, 1998; 26: 54-57.

Semwal DK, Rawat U. Gindarudine, a novel morphine alkaloid from Stephania glabra. Chin Chem Lett. 2009; 20: 823-26. 